\title{
Assessment of Point-of-Use Membrane-Based Drinking Water Appliance for Local Community
}

\author{
Yusuf Wibisono $^{1,4, *}$, Restu Vitri Astuti², Gunomo Djoyowasito ${ }^{2}$, Angky Wahyu Putranto ${ }^{1}$, Nimatul \\ Izza $^{1}$, Dikianur Alvianto ${ }^{1}$ and Sucipto ${ }^{3}$
}

\author{
${ }^{1}$ Department of Bioprocess Engineering, Brawijaya University, Malang, Indonesia \\ ${ }^{2}$ Department of Agriculture and Biosystem Engineering, Brawijaya University, Malang,Indonesia \\ ${ }^{3}$ Department of Agro-industrial Technology, Brawijaya University, Malang, Indonesia \\ ${ }^{4}$ MILI Institute for Water Research, Bekasi, Indonesia
}

Received 11 December 2019; Accepted 30 May 2021

\begin{abstract}
Developing countries, such as Indonesia, has abundance of water resources, either fresh and salty water. However, improved drinking water is still uneasy to access. While centralized water treatment facilities do not provide a ready use drinking water due to expensive cost and extensive on-site process or distribution system, bottled water generally accepted for daily consumption. Nevertheless, bottled drinking water is significantly expensive and the left over used plastic bottle become major contributor for plastic pollution. A mobile and compact point-of-use drinking water treatment appliance is a pivotal answer to provide clean, healthy and low cost drinking water and user-friendly instrument for low income households and communities. This paper reported design and assessment of the device. Water qualities were measured for biological, physicals and chemicals properties, and met the International Organization for Standardization (ISO) 5667-5: 2006, for instance nitrate content was decreased from $33.36 \mathrm{mg} / \mathrm{L}$ to $4.6 \mathrm{mg} / \mathrm{L}$; nitrite content decreased from $0.1169 \mathrm{mg} / \mathrm{L}$ to $0.0248 \mathrm{mg} / \mathrm{L}$; ammonia content decreased from $0.2693 \mathrm{mg} / \mathrm{L}$ to $0.16 \mathrm{mg} / \mathrm{L}$; manganese content decreased from $0.015 \mathrm{mg} / \mathrm{L}$ to $0.0136 \mathrm{mg} / \mathrm{L}$ and fluoride content decreased from $4.721 \mathrm{mg} / \mathrm{L}$ to $<0.00625 \mathrm{mg} / \mathrm{L}$. Long term application of 30 days operation was also reported. The volumetric flowrates were stable at $16-22 \mathrm{~L} / \mathrm{min}$ and the hydraulic pressure were constant at about 0.6 bar behind UF membrane, indicated very low fouling observed. The design is finally could be adapted and implemented in any local and low income communities worldwide, to maintain the supply of healthy and safe drinking water.
\end{abstract}

Keywords: Point-Of-Use, Drinking Water Treatment, Ultrafiltration, Membrane, Ultraviolet, Local Community

\section{Introduction}

Water is very valuable resource, a paramount for food and energy nexus [1.. Water is required to produces food and important aspect to provide energy for human activities. Clean water supply becomes essential need for people, either in developed or in developing countries. While centralized drinking water treatment provide substansial reserve for developed countries, the contrary condition being occured for developing countries [2]. Centralized drinking water treatment involves higher capital expenses for main treatment unit, piping and pumping, meanwhile provides healthy and sufficient clean water [3]. Thereupon, bottled drinking water is consumed extensively in many developing countries due to expensive and extensive process of centralized drinking water facilities [4]. It is estimated 275 tonnes of plastic wastes produces annually in the world. Problem raised from plastic waste from bottled drinking water become very common in developing countries, including in rural communities $[5,6]$.

In order to provide sufficient clean drinking water supply, low-cost, grid-independent and easy to handle, a point-of-use (PoU) system is an alternative solution [7]. Typically, a PoU system consist of physical-based water treatment using absorption, filtration and disinfection

*E-mail address: Y_Wibisono@ub.ac.id

ISSN: 1791-2377 @ 2021 School of Science, IHU. All rights reserved.

doi:10.25103/jestr.145.01 systems [8]. Absorption using carbon active is commonly used for a PoU system [9]. A membrane-based filtration system is widely used for PoU system, due to robust capability to provide drinking water supply [10]. However, membrane filtration for drinking water treatment also suffered from fouling, i.e. organic, inorganic or biological fouling $[11,12]$. Nonetheless, point-of-use drinking water treatment could reduce the fouling potential, especially for biological type fouling such as bacterial and its extracellular polymeric substance [13]. Due to this finding, the utilization of point-of-use drinking water treatment is promising, particularly in the region where centralized drinking water systems unable to install, due to cost restriction or remote location [14].

In this study, a design of mobile UF (ultrafiltration) based point-of-use drinking water appliance was developed and implemented in local communities. The appliance consists of sand and activated carbon filters to remove organic debris and particles, and ultrafiltration to remove unwanted macromolecules such as humic and also harmful microorganisms. Moreover, the ultraviolet (UV) emmited to kill remain microorganism and preventing infection.

Membrane-based drinking water appliance was selected due to high efficiency rate of the technology. Even membrane-based drinking water appliance could be operated either by using electric or non-electric pressure driven systems [7]. UF process could eliminate pathogenic 
microorganisms as well as inorganic contaminants [11]. A cheaper option filtration process by using sand filtration also widely used prior to membrane unit, enhancing the water quality produced [7]. While, activated carbon capability to adsorb contaminants present in water also long-established [2]. As for UV treatment, could be used to induce DNA structural falsification, prevent transcription and replication and furthermore promote cell casualties [15]. Moreover, UV also induces oxidation which lead to a deterioration of organic contaminants in water [16]. A long term operational assesment was also conducted to evaluate the capability and feasibility of the appliance. This study is aiming at the implementation of meso-scale drinking water supply for local communities, especially in remote areas.

\section{Experimental Methods}

\subsection{Materials}

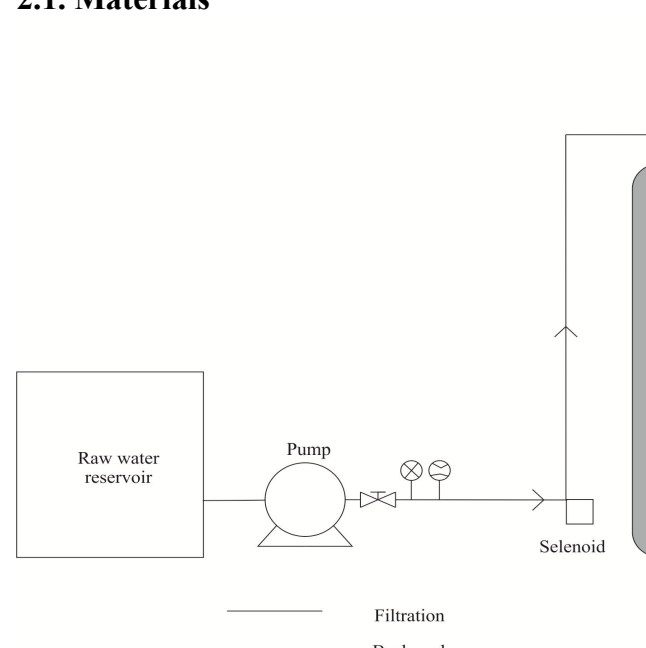

Fig. 1. Schematic diagram of mobile point of use drinking water appliance
The appliance consist of three different parts, i.e.: treatment materials, treatment process equipment and frame supporting materials. Silica sand, powdered activated carbon, cartridge filter, hollow fiber ultrafiltration membrane and UV sterilisator were used as treatment materials. Fiber reinforced plastics (FRP) filter tube, 3 way valve, pump, polyvinyl chloride (PVC) water piping, selenoid, pressure gauges, flowmeter, feed tank with a buoy, and faucets were used as treatment process equipment. Finally, stainless steel 304 plate, iron plate, and hollow iron tube were utilized as frame supporting materials.

\subsection{Functional and Structural Design}

The main function of the appliance is to provide high quality of drinking water for small communities. The raw water at first treated by silica sand and activated carbon filter, then processed in series of cartridge filter and UF membrane, before finally going through UV light sterilization. Figure 1 depicted the schematic diagram of the process.
Figure 2 shows the 3D-graphical design of mobile pointof-use drinking water appliance. The water treatment started by collecting raw water into a $1050 \mathrm{~L}$ feed tank. The raw water should produced from a pre-treatment process to remove debris or other large particles. In order to maintain a long term utilization of the device, a minimum standard of raw water material should follow a standard of tap water quality. From the feed tank, the raw water will pass the $3 / 4$ inch piping system made of PVC material (Rucika Pipes, Indonesia) and each treatment unit until is ready to drink. A semi-jet pump (Goldenfoss-250, Indonesia) pressurized water into filtration system and provide sufficient driving force for the ultrafiltration membrane. The pump required electricity of $250 \mathrm{~W}, 220 \mathrm{~V}$ and could provide $11 \mathrm{~m}$ head power and capacity of 4600 liters/hour. The raw water was then firstly entered a FRP 1054 filter tube (KSH, Indonesia) with diameter of 10 inches and $1500 \mathrm{~mm}$ height. It contains as much $50 \mathrm{~kg} \mathrm{8-16} \mathrm{mesh} \mathrm{silica} \mathrm{sand} \mathrm{(Alinco,} \mathrm{Indonesia)} \mathrm{and}$ occupied approximately $65 \mathrm{~cm}$ of total height of the tube.

Silica sand filter was used to filter large particles in water such as mud and soil. The water was then entered another FRP 1054 filter tube containing as much $25 \mathrm{~kg} \mathrm{8-30}$ mesh activated carbon (Haycarb, Srilanka) and occupied approximately $70 \mathrm{~cm}$ from height of tube. The activated carbon has iodine value of 1000-1050 mg/g. Activated carbon filter was used to filter organic matter, odor, and metal substances. Since both filters were normally suffered from any type of fouling materials, the piping system was also designed to provide backwash line by change the flow direction using 3-way valve. The backwash could provide the periodic cleaning of the membrane. Subsequently, the water flowed into a series of 4 cartridge filters (Nanotec, USA) with pore size of $0.1 \mu \mathrm{m}$. The filter housing used a clear housing to facilitate visual controlling of the filter to measure exact time for cleaning or replacing. By cartridge filter, normally only certain microbes which could passed through, allowing the biofilm growth in the filter surface. It is therefore serial fiters were installed in order to maintain switches of the filters.
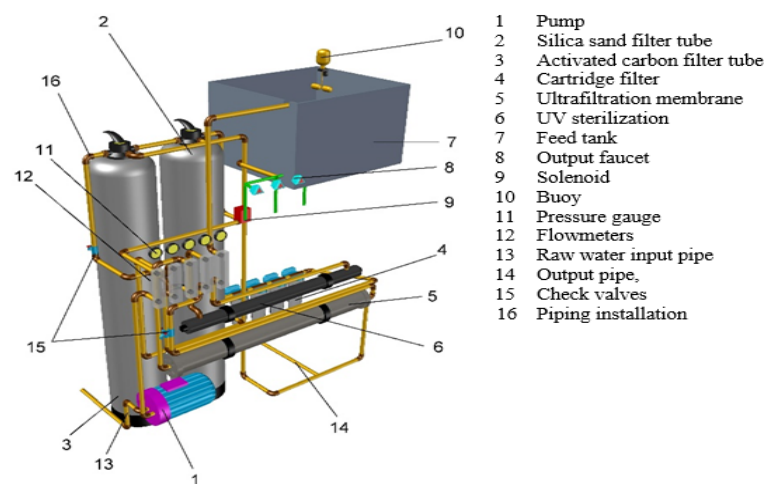

Fig. 2. Design of mobile point-of-use drinking water appliance 
After treated in cartridge filter, the water was then treated in ultrafiltration hollow fiber membrane (Hyna $\mathrm{HN}$ UF 4040, China) with pore size of approxymately $10 \mathrm{~nm}$. The UF membrane module has diameter of 4 inches, length of $1061 \mathrm{~mm}$, and capable to handle flow rate of 300-500 L/hour and operated at pressure of 1-5 bar. UF filter prevented the colloid particles and microbes, including viruses and coliform to pass through its pores, while salts and minerals were still able to pass trough, thus providing high quality of drinking water.

Final treatment provided by 12 GPM ultraviolet lamp (KSH, Indonesia) with wavelength of $254 \mathrm{~nm}$. The wavelength lies on UV-C spectrum which $254 \mathrm{~nm}$ is the highest peak for bacterial inactivation [17]. The sterilizer was covered housing stainless steel $304 \mathrm{~L}$ with $920 \mathrm{~mm}$ length and $64 \mathrm{~mm}$ diameter, has channel duct of $3 / 4$ inches, glass sleeve, UV ballast of 40 Watts, O-ring, and clamp. The UV sterilize water by eliminating microorganism, thus final product water was comply drinking water standard in term of physical, chemical and biological properties.

Final water product collected in a stainless steel 304 tank, plate thickness of $1.5 \mathrm{~mm}$, with dimensions of $600 \mathrm{~mm} \mathrm{x}$ $541.6 \mathrm{~mm} \times 400 \mathrm{~mm}$ and capacity of 130 liters. Inside the tank, a buoy was installed $10 \mathrm{~cm}$ from upper level of the tank. It connected to solenoid valve, and provided an automatic system to set the pump shutted or on, and maintain the tank filled with $70-80 \%$ product water. When the drinking water tank reaches upper limit of the buoy, the pump will be automatically shut down and selenoid valve closed. When it reaches lower limit of the buoy, the pump will automatically start and the solenoid opened. By the control system, could also reduce the use of electricity. When the user want to drink, they could use the clean water by opening 3 pieces of output faucets.

In the piping system, 5 GPM flow meters were installed to measure volumetric flow rate of the water between the treatment units, including water flow through pump, filter tubes, cartridge filters, ultrafiltration membrane and backwash flow. In order to measure the pressure developed in the treatment units, 2.5 bar pressure gauges were installed. The pressure gauges were installed in the piping system which specifically located at the flow through the pump, adsorbent tubes, cartridge filters, ultrafiltration membrane and UV sterilization.
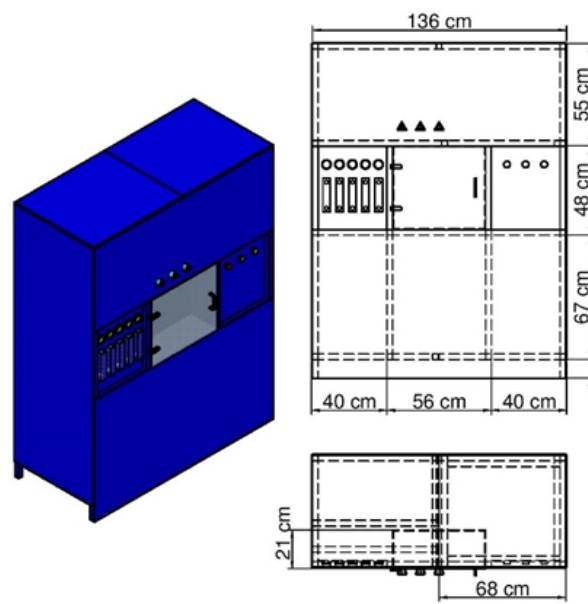

Fig. 3. Design of supported frame for mobile point-of-use drinking water appliance.

This appliance is finally served as integrated filtration system using macro filters, micro filters, ultrafiltration membrane and sterilization using UV radiation, designed as a direct supply of drinking water solutions. The appliance was framed by using frame supporting materials made from perforated iron with size $30 \mathrm{~mm}$ and iron plates (see Figure 3). The final appliance dimension was $1360 \mathrm{~mm}$ x $600 \mathrm{~mm} \times$ $1800 \mathrm{~mm}$, with the total empty weight approximately $100 \mathrm{~kg}$. By this dimension and weight, the device could transported easily by using a small cargo car to remote area or for using as emergency drink water source during crisis or disaster. The appliance parts can be connected and disconnected easily, in order to maintain transportability.

\subsection{Method for Water Quality Assessment}

Assesment is important before apply the device in the application site, and very useful to check the appliance is working properly as expected. Assesment was consisted of testing for device performance and quality of drinking water produced.

Physical, chemical and biological properties of raw water, water treated by macrofilters (sand and activated carbon filters), water treated by cartridge filters, water treated by ultrafiltration membrane and final product water after UV sterilization were tested in the lab. Drinking water quality should meet the standard quality of the Regulation of the Minister of Health of the Republic of Indonesia Number 492 Year 2010, and the World Health Organization (WHO) covering microbiological, chemical, and physical parameters $[18,19]$. The biological parameter includes Escherichia coli and total coliform numbers. The physical parameter consists of odor, taste, total dissolve solid (TDS), turbidity and temperature. While chemical parameter comprises the amount of nitrate, nitrite, manganese, hardness, chloride, ammonia, $\mathrm{pH}$, fluoride, sulfate, cyanide, color, arsenic, cadmium, copper, total chrome, selenium, zinc, aluminum and iron.

The water samples were tested in accredited laboratories to ensure accurate testing results. The number, frequency and sample points are based on conditions and depend on the type of inspection performed. Physical and chemical properties examination requires \pm 1.5 liters of water, and bacteriological examination requires $\pm 100 \mathrm{~mL}$ of water. Sampling and conditioning of the samples are carried out aseptically according to procedures based on the Indonesian National Standard (SNI) 7828: 2012, equivalent with the International Organization for Standardization (ISO) 5667-5: 2006, concerning drinking water sampling.

\subsection{Long-Term Operational Assessment}

Operational assessment of the appliance consisted of several parameters such as volumetric flowrate, pressure, temperature, TDS, and $\mathrm{pH}$. Water flowrates were measured by flowmeters at each inspection node, namely after pump, after macrofilter, after microfilter, after ultrafiltration membrane and after UV sterilization. The measurements were repeated 8 times for $150 \mathrm{~L} /$ day of drinking water produced.

Pressure measurement was done by measuring water pressure after pump, after macrofilter, after microfilter, after ultrafiltration membrane and backflow of ultrafiltration membrane. It observed changes from pressure gauge, repeated 8 times for $150 \mathrm{~L} /$ day of drinking water produced. Measurement of temperature, TDS and $\mathrm{pH}$ were done using Sensordirect-150 water testing (Lovibond, UK). Samples of raw water, water after macrofilter, water after microfilter, water after ultrafiltration membrane and water after UV sterilization were evaluated. In order to investigate the stability of operational condition, the observation was 
conducted for 30 days (28 days without backwash and 2 days with backwash). Backwash normally conducted when the initial fouling occurred, when the pressure across the filter increasing, due to fouling restriction. However, periodic backwash can be conducted to maintain the system clean dan prevent irreversible fouling occurred [11].

\section{Results and Discussion}

\subsection{Water Product Quality}

The laboratory results of water quality was summarized in Table 1. Based on the results of laboratory testing, some water samples showed a change on physical and chemical properties. Some parameters including TDS, turbidity, nitrate, nitrite, manganese, ammonia and fluoride were decreased. As shown, the TDS value increased after macro filtering from $100.3 \mathrm{mg} / \mathrm{L}$ to $199 \mathrm{mg} / \mathrm{L}$ and also decreasing TDS after micro filter until UV sterilization became 159.4 $\mathrm{mg} / \mathrm{L}$. Similar results are found elsewhere [20]. TDS values represent the number of dissolved substances (organic and inorganic substances) present in the solution. The increase in TDS of water after treated in activated carbon bed was caused by some activated carbon particles dissolving into water as colloid particles and was not able to be settling.

Nitrate content was decreased from $33.36 \mathrm{mg} / \mathrm{L}$ to 4.6 $\mathrm{mg} / \mathrm{L}$; nitrite content decreased from $0.1169 \mathrm{mg} / \mathrm{L}$ to 0.0248 $\mathrm{mg} / \mathrm{L}$; ammonia content decreased from $0.2693 \mathrm{mg} / \mathrm{L}$ to 0.16 $\mathrm{mg} / \mathrm{L}$; manganese content decreased from $0.015 \mathrm{mg} / \mathrm{L}$ to $0.0136 \mathrm{mg} / \mathrm{L}$ and fluoride content decreased from 4.721 $\mathrm{mg} / \mathrm{L}$ to $<0.00625 \mathrm{mg} / \mathrm{L}$. Effectiveness of decreasing parameters when passing macrofilter and microfilter such as nitrate is $81 \% ; 25 \%$ decrease on nitrite; $74 \%$ decreased on ammonia, $99.8 \%$ decrease on fluoride and $30 \%$ decreased on chloride. The removal by UV light treatment was higher for nitrate, nitrite and hardness compared to other units, since UV could stimulate oxidation of the molecules [16].

As for biological properties, percentage of microorganisms removed by ultrafiltration membrane was $86 \%$. Ultrafiltration has pore size which is able to restrict bacteria cells and virus particles to pass through [11]. Moreover, the UV light also able to eliminate microorganism cells [17]. Based on the analysis of laboratory test results according to the Regulation of the Ministry of Health of the Republic of Indonesia and the World Health Organization, concerning drinking water requirements, it is said that raw water meets the requirements except for the fluoride parameters. The final product water especially, was in accordance with 26 standard parameters and was suitable for drinking water.

\subsection{Long term operation}

\subsubsection{Volumetric flowrate}

Figure 4 shows the periodic volumetric flowrate in each treatment unit of the device, up to 30 days.

As shown in Figure 4, the volumetric flow rate observed daily were relatively contant, including before and after backwash. The average flow rate of raw water, after macrofilters, after microfilters, after UF membranes and after UV sterilization were $22 \mathrm{~L} / \mathrm{min}, 16 \mathrm{~L} / \mathrm{min}, 15.5 \mathrm{~L} / \mathrm{min}$, $20 \mathrm{~L} / \mathrm{min}$ and $19.5 \mathrm{~L} / \mathrm{min}$, respectively. The decreasing and increasing of volumetric flow rates were occured due to water friction in filter media such as silica sand, activated carbon media, cartridge filters and ultrafiltration membranes. When suspended solids begins to block filter media, the flow rate become flowing slowly. Filtration flowrates affected by pressure drop, filter contact area, filtration flow velocity, cake resistance and filter media resistance.

Table 1. Water Quality Parameters Testing Results

\begin{tabular}{|c|c|c|c|c|c|c|c|}
\hline Parameters & Units & $\begin{array}{c}\text { Standard } \\
(\max )\end{array}$ & $\begin{array}{c}\text { Raw } \\
\text { Water }\end{array}$ & Macrofilter & Microfilter & $\begin{array}{c}\text { UF } \\
\text { Membrane }\end{array}$ & UV \\
\hline \multicolumn{8}{|l|}{ Biologicals } \\
\hline E. coli & $\begin{array}{c}\text { MPN/100 } \\
\mathrm{mL}\end{array}$ & 0 & 0 & 0 & 0 & 0 & 0 \\
\hline Coliform & $\begin{array}{c}\text { MPN/100 } \\
\mathrm{mL}\end{array}$ & 0 & 0 & 0 & 0 & 0 & 0 \\
\hline \multicolumn{8}{|l|}{ Physicals } \\
\hline Odor & - & odorless & odorless & odorless & odorless & odorless & odorless \\
\hline Taste & - & tasteless & tasteless & tasteless & tasteless & tasteless & tasteless \\
\hline TDS & $\mathrm{mg} / \mathrm{L}$ & 500 & 100.3 & 199 & 196 & 194 & 159.4 \\
\hline Turbidity & NTU & 5 & 0.86 & 0 & 0 & 0 & 0.54 \\
\hline Temperature & ${ }^{\circ} \mathrm{C}$ & \pm 3 & 26.1 & 25 & 25 & 25 & 26.1 \\
\hline \multicolumn{8}{|l|}{ Chemicals } \\
\hline Nitrate $\left(\mathrm{NO}_{3}\right)$ & $\mathrm{mg} / \mathrm{L}$ & 50 & 33.36 & 6.078 & 6.65 & 6.5 & 4.6 \\
\hline Nitrite $\left(\mathrm{NO}_{2}\right)$ & $\mathrm{mg} / \mathrm{L}$ & 3 & 0.1169 & 0.082 & 0.105 & 0.109 & 0.0248 \\
\hline Manganese & $\mathrm{mg} / \mathrm{L}$ & 0.4 & 0.015 & 0.0001 & 0.0001 & 0.0001 & 0.0136 \\
\hline Hardness & $\mathrm{mg} / \mathrm{L}$ & 500 & 81 & 133.32 & 123.22 & 129.28 & 86 \\
\hline Chloride $\left(\mathrm{Cl}^{-}\right)$ & $\mathrm{mg} / \mathrm{L}$ & 250 & 6.6 & 4.96 & 4.56 & 4.56 & 6.1 \\
\hline Ammonia & $\mathrm{mg} / \mathrm{L}$ & 1.5 & 0.2693 & 0.07 & 0.29 & 0.195 & 0.16 \\
\hline $\mathrm{pH}$ & - & $7.5-8.5$ & 7.54 & 7.5 & 7.5 & 7.5 & 7.45 \\
\hline Fluoride & $\mathrm{mg} / \mathrm{L}$ & 1.5 & $4.721 *$ & - & - & - & $<0.0625$ \\
\hline Sulfate & $\mathrm{mg} / \mathrm{L}$ & 250 & 0.2815 & - & - & - & 0.4946 \\
\hline Cyanide & $\mathrm{mg} / \mathrm{L}$ & 0.07 & $<0.001$ & - & - & - & $<0.001$ \\
\hline Color & Pt.CO & 15 & $<0.261$ & - & - & - & $<0.261$ \\
\hline Arsenic & $\mathrm{mg} / \mathrm{L}$ & 0.01 & $<0.0004$ & - & - & - & $<0.0004$ \\
\hline
\end{tabular}




\begin{tabular}{|c|c|c|c|c|c|c|c|}
\hline Cadmium & $\mathrm{mg} / \mathrm{L}$ & 0.003 & $<0.0015$ & - & - & - & $<0.0015$ \\
\hline Copper & $\mathrm{mg} / \mathrm{L}$ & 2 & $<0.0117$ & - & - & - & $<0.0117$ \\
\hline Total chrome & $\mathrm{mg} / \mathrm{L}$ & 0.05 & $<0.01$ & - & - & - & $<0.01$ \\
\hline Selenium & $\mathrm{mg} / \mathrm{L}$ & 0.01 & $<0.0003$ & - & - & - & $<0.0003$ \\
\hline Zinc & $\mathrm{mg} / \mathrm{L}$ & 3 & 0.0065 & - & - & - & 0.0087 \\
\hline Aluminum & $\mathrm{mg} / \mathrm{L}$ & 0.2 & $<0.0103$ & - & - & - & $<0.0103$ \\
\hline Iron & $\mathrm{mg} / \mathrm{L}$ & 0.3 & $<0.0003$ & - & - & - & $<0.0003$ \\
\hline
\end{tabular}

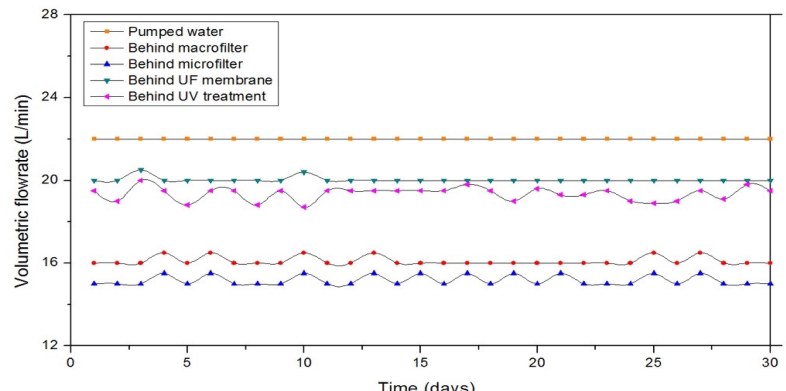

Fig. 4. Volumetric flow rate for 30 days (28 days of before backwash and 2 days of after backwash)

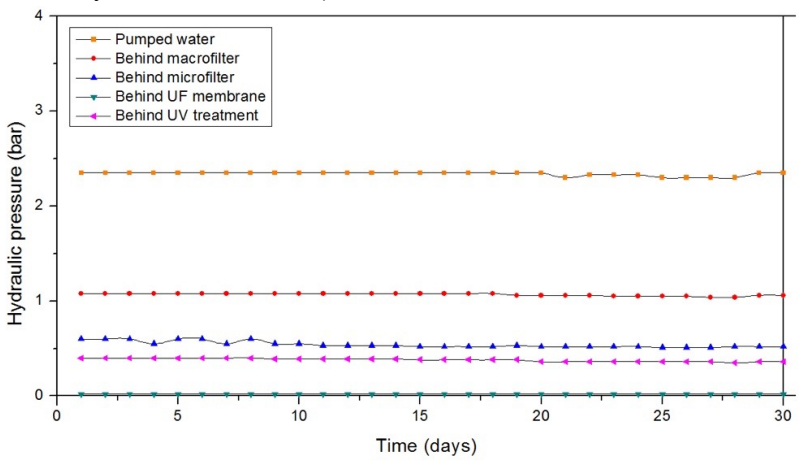

Fig. 5. Pressure values for 30 days (28 days of before backwash and 2 days of after backwash)

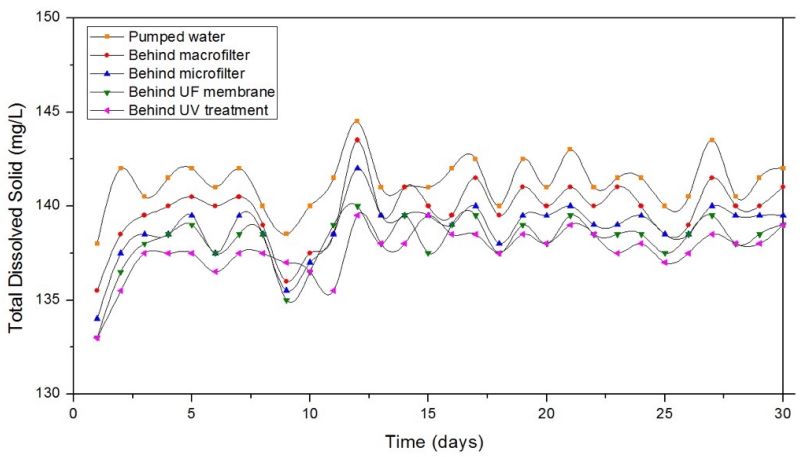

Fig. 6. Total Dissolve Solid for 30 days (28 days of before backwash and 2 days of after backwash)

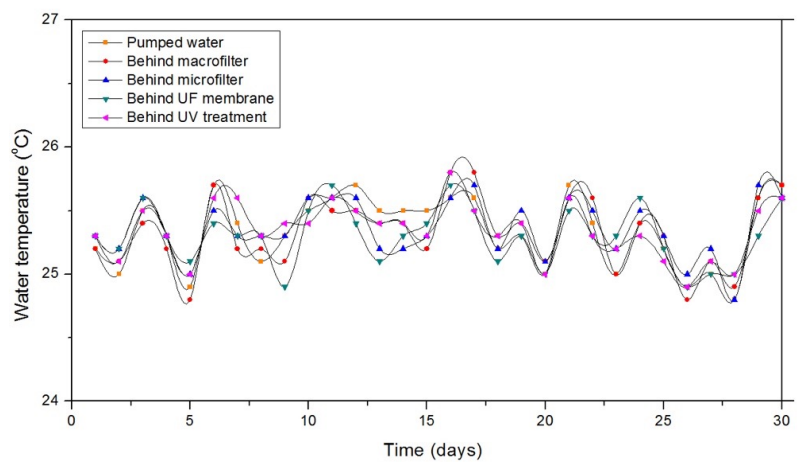

Fig. 7. Temperature values for 30 days ( 28 days of before backwash and 2 days of after backwash)

\subsubsection{Pressure difference}

Figure 5 shows the the pressure behavior of the flowing water in the treatment unit, including raw water, water after macro filter, water after micro filter, water after ultrafiltration membrane and backflow of ultrafiltration membrane, for long term observation up to 30 days.

Similar to flowrate behavior, the pressure as observed daily was also relatively similar. The average preassure of raw water was 2.33 bar; after macrofilter was 1.06 bar; after microfilter was 0.54 bar; after ultrafiltration membrane was 0.02 bar; and backflow of UF membrane was 0.37 bar. After UV sterilization, the pressure is small because the flow does not have any obstacles such as filters or others.

\subsubsection{Total Dissolved Solid}

Measurement of total dissoved of water sample for 30 days were also taken from raw water, water after macro filter, water after micro filter, ultrafiltration membrane water and water after UV and shown in Figure 6.

As shown, the average TDS values before the backwash were $141.2 \mathrm{mg} / \mathrm{L}$ for raw water; $139.7 \mathrm{mg} / \mathrm{L}$ after macrofilters; $138.7 \mathrm{mg} / \mathrm{L}$ after microfilter; $138 \mathrm{mg} / \mathrm{L}$ after UF membrane filter; and $137.5 \mathrm{mg} / \mathrm{L}$ after UV treatment. After backwash, the average TDS for 2 days of raw water was $140 \mathrm{mg} / \mathrm{L}$; after macrofilters was $139.9 \mathrm{mg} / \mathrm{L}$; after microfilter was $139 \mathrm{mg} / \mathrm{L}$; after ultrafiltration membrane was $138.4 \mathrm{mg} / \mathrm{L}$; and after UV sterilization was $138.3 \mathrm{mg} / \mathrm{L}$. TDS values before and after the backwash were relatively similar, but decreased every process.

\subsubsection{Water Temperature}

Observation of water temperature from each treatment unit for 30 days was relatively constant. The temperature was ranged between $24.5^{\circ} \mathrm{C}$ to $26^{\circ} \mathrm{C}$ as shown in Figure 7 .

\subsection{5. pH Value}

As for $\mathrm{pH}$ value, as observed daily up to 30 days, shown in Figure 8.

Before backwash, the average $\mathrm{pH}$ for 28 days of raw water was 7.02; after macrofilter was 7.24; after microfilter was 7.27; after ultrafiltration membrane was 7.28; and after UV sterilization was 7.28. After backwash, the average $\mathrm{pH}$ for 2 days of raw water was 6,97; after macrofilter was 7.21; after microfilter was 7.25; after ultrafiltration membrane was 7.26; and after UV sterilization was 7.28. As mentioned, the $\mathrm{pH}$ values before and after the backwash were relatively the same, but increasing slightly every treatment process. The highest increase was observed after activated carbon filtration process. Activated carbon is a binding of metal ions in solution. In the filtration process, metal elements in water would be broken down into metal ions and hydroxide ions. Metal ions would be attracted by activated carbon until the remaining $[\mathrm{OH}-]$ ions reduced, $[\mathrm{H}+]$ ions cause an increase in $\mathrm{pH}$, although not significant.

\subsection{Cost analysis and user satisfaction index}


Manufacturing cost of the device was not more than 1500 USD, based on Indonesian retail price. The device could produce drinking water approximately 150 liters per hour or 3600 liters per day, and could provide drinking water for approximately 144 households, assumed that every person consumed drinking water about 5 liters per day [21]. Compared with centralized systems, the operational cost may be higher, but the capital cost is much lower [22, 23]. It is therefore the device as very suitable for low income communities or local community during period of emergencies or disasters. The device was manufactured and installed in an elementary school as small communities. Based on the recent study reported elsewhere, the user satisfaction was higher as evaluated based on Importance Performance Analysis (IPA) and Customer Satisfaction Index (CSI) with the values of $93.20 \%$ and $76 \%$, respectively [24].

\section{Conclusion}

Mobile UF-based point-of-use drinking water treatment appliance was developed and evaluated. Operational evaluation were conducted for 30 days, and as observed volumetric flowrate and hydraulic pressure were relatively constant. When backwash process conducted at the 28th day, the effect was not significant. The physical, chemical and biological properties of produced water were complied with the Regulation of the Minister of Health of the Republic of Indonesia and the World Health Organization standards. Based on the evaluation, the mobile device could be used for water treatment for providing high quality of drinking water for low income communities.

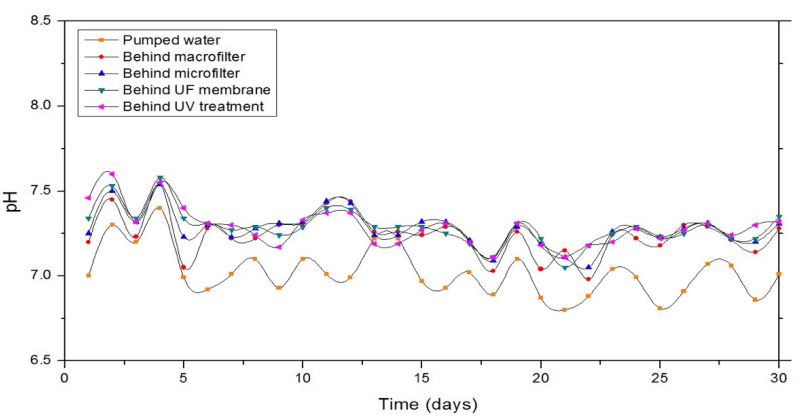

Fig. 8. $\mathrm{pH}$ Values for 30 days ( 28 days of before backwash and 2 days of after backwash)

\section{Acknowledgement}

We acknowledge Faculty of Agricultural Technology Brawijaya University for providing funding for conducting the research activities. Thanks to teachers and students of SDIT Insantama Malang for providing facilities during long term assessment of the device.

$\begin{array}{ll}\text { Nomenclature } \\ \text { PoU } & \text { Point of Use } \\ U V & \text { Ultraviolet } \\ \text { FRP } & \text { Fiberglass Reinforced Plastics } \\ P V C & \text { Polyvinyl Chloride } \\ U F & \text { Ultrafiltration } \\ \text { SNI } & \text { Indonesian National Standard } \\ \text { GPM } & \text { Gallons Per Minute } \\ W H O & \text { World Health Organization } \\ \text { ISO } & \text { International Organization for Standardization } \\ \text { TDS } & \text { Total Dissolved Solids } \\ \text { MPN } & \text { Most Probable Number }\end{array}$

This is an Open Access article distributed under the terms of the Creative Commons Attribution License.

\section{References}

1. Wibisono, Y; Agung Nugroho, W; Akbar Devianto, L; Adi.Sulianto, A.; Roil Bilad, M. (2019) Microalgae in FoodEnergy-Water Nexus: A Review on Progress of Forward Osmosis Applications. Membranes, 9, 166

2. Wibisono, Y., Sucipto, S., Perdani, C.G., Astuti, R., Dahlan, M. (2018). Halal compliance on drinking water industries: a future perspective, Proceeding of the 3rd International Halal Conference (INHAC2016); Muhammad, H.N.; Md Shariff, N.; Mahamood, S.; Fathullah, H.H.; Shahruddin, M.; Bhari, A., Eds.; Springer: Singapore.

3. Ma, X.; Xue, X.; González-Mejía, A.; Garland, J.; Cashdollar, J., (2015) Sustainable Water Systems for the City of Tomorrow-A Conceptual Framework. Sustainability, 7, 12071-12105

4. Orset, C., Barret, N., Lemaire, A. (2017) How consumers of plastic water bottles are responding to environmental policies?, Waste Management, Volume 61, Pages 13-27,

5. Nxumalo, S.M., Mabaso, S.D., Mamba, S.F., Singwane, S.S. (2020), Plastic waste management practices in the rural areas of Eswatini, Social Sciences \& Humanities Open, Volume 2, Issue 1,100066.

6. Wardrop, N.A., Dzodzomenyo, M., Aryeetey, G., Hill, A.G., Bain, R.E.S., Wright, J. (2017) Estimation of packaged water consumption and associated plastic waste production from household budget surveys. Environmental Research Letters, Volume 12, Number 7, Pages 4029.

7. Pooi, C.K and Ng, H.Y. (2018). Review of low-cost point-of-use water treatment systems for developing communities, NPJ Clean Water, 1(1), 11.

8. Mahlangu, T.O. (2011). Design and evaluation of a cost effective household drinking water treatment system. Master Thesis. University of Johannesburg, South Africa.
9. Sukoyo, A., Djoyowasito, G., Wibisono, Y. (2019). Unravelling the Potency of Activated Carbon Powder Derived from Cultivated Marine Microalgae as a Promising Filler in Mixed Matrix Membranes. Agri. Engineering 1, 188-204.

10. Shamsuddin, N., D. B. Das \& V. M. Starov. (2016). MembraneBased Point-Of-Use Water Treatment (PoUWT) System in Emergency Situations. Separation \& Purification Reviews, 45(1), 50-67

11. Wibisono, Y. (2014). Two-phase flow for fouling control in membranes. PhD Thesis. University of Twente, The Netherland.

12. Liu, S., Gunawan, C., Barraud, N., Rice, S. A., Harry, E. J., and Amal, R., (2016) Understanding, Monitoring, and Controlling Biofilm Growth in Drinking Water Distribution Systems, Environmental Science and Technology, vol. 50, no. 17, pp. 89548976.

13. Chawla, C., Zwijnenburg, A., Kemperman, A.J.B., Nijmeijer, K., (2017) Fouling in gravity driven Point-of-Use drinking water treatment systems, Chemical Engineering Journal, Volume 319, Pages 89-97.

14. Sobsey, M.D., Stauber, C.E., Casanova, L.M., Brown, J.M., Elliott, M.A. (2008) Point of Use Household Drinking Water Filtration: A Practical, Effective Solution for Providing Sustained Access to Safe Drinking Water in the Developing World, Environmental Science \& Technology, 42, 12, 4261-4267.

15. Gouma, M., Gayán, E., Raso, J., Condón, S., Álvarez, I. (2015). UV-Heat Treatments for the Control of Foodborne Microbial Pathogens in Chicken Broth, BioMed Research International, vol. 2015, 12 pages.

16. Wols, B.A., Hofman-Caris, C.H.M. (2012), Review of photochemical reaction constants of organic micropollutants 
Yusuf Wibisono, Restu Vitri Astuti, Gunomo Djoyowasito, Angky Wahyu Putranto, Nimatul Izza, Dikianur Alvianto and Sucipto/

\section{Journal of Engineering Science and Technology Review 14 (5) (2021) 1 - 7}

required for UV advanced oxidation processes in water, Water Research, Volume 46, Issue 9, Pages 2815-2827.

17. Timmermann, L.F., Ritter, K., Hillebrandt, D., Küpper, T., (2015) Drinking water treatment with ultraviolet light for travelers Evaluation of a mobile lightweight system, Travel Medicine and Infectious Disease, Volume 13, Issue 6, Pages 466-474.

18. Goncharuk, V. (2013) The new standard for drinking water. Journal of Chemistry, 321609.

19. Akter, T., Jhohura, F.T., Akter, F., Chowdury, T.R., Mistry, S.K., Dey, D., Barua, M.K., Islam, M.A., Rahman, M. (2016), Water Quality Index for measuring drinking water quality in rural Bangladesh: a cross-sectional study, Journal of Health, Population and Nutrition 35: 4.

20. Rahmawati, Wilaksono,A., Amri, N., Davidson, K.N, Rimawan, B., Heriyanti. (2018). Adsorption of Peat Water Using Activated Carbon from Bintaro Fruits. Chempublish Journal 2(2), 253-4588.
21. Grandjean, A.C. (2005) Water requirements, impinging factors, and recommended intakes. Nutr Drink Water. 1-196.

22. Schuerhoff M.S., Hellegers P. (2015) Water Pricing in the Netherlands. In: Dinar A., Pochat V., Albiac-Murillo J. (eds) Water Pricing Experiences and Innovations. Global Issues in Water Policy, vol 9. Springer, Cham.

23. Hofman-Caris, R.; Bertelkamp, C.; de Waal, L.; van den Brand, T.; Hofman, J.; van der Aa, R.; van der Hoek, J.P. (2019) Rainwater Harvesting for Drinking Water Production: A Sustainable and CostEffective Solution in The Netherlands? Water, 11, 511.

24. Putranto, A.W., Izza,N., Wibisono, Y., Argo, B.D. (2020), Implementation of drinking water treatment device for primary school students and teachers (Case study at SDIT Insantama Malang, Indonesia), IOP Conf. Ser.: Earth Environ. Sci. 524 012023 